\title{
Introduction: conceptual, methodological, practical, and ethical challenges in studying and applying indigenous knowledge
}

\author{
Courtney Carothers $^{1}$, Mark Moritz $^{2}$ and Rebecca Zarger $^{3}$
}

Key Words: collaborative methodology; indigenous education; indigenous knowledge; indigenous knowledge change; practice theory; traditional ecological knowledge

For over a half a century, indigenous knowledge systems have captured the attention of anthropologists (Hunn 2007). Recently, interest has intensified both inside and outside the discipline among scholars and practitioners in a wide variety of contexts ranging from international development, resource management, sustainability and resilience, disaster response, climate change, ethnobotany, ethnomedicine, and ethnoveterinary studies (ReyesGarcia et al. 2009, UNESCO 2009, Maffi and Woodley 2010). Simultaneously, sophisticated conceptual and methodological approaches have been developed, such as cultural consensus analysis and participatory mapping. Many of these recent advances tend to rely on theories of knowledge that focus attention on mental models and discrete, encapsulated, and abstracted aspects of knowledge that can be documented using formal interview methods (e.g., freelists, triads, pile sorts, surveys) (Zent 2009). However, a growing number of anthropologists have found that these approaches and techniques constrain descriptions and obscure the hybrid and heterogeneous nature of indigenous or local knowledge and modes of understanding (see Spoon 2014, Carothers et al. 2014). For example, as Lauer and Aswani (2009) note, "More research is needed to develop approaches and methods that can empirically record aspects of knowledge and understanding that are commonly ignored in indigenous knowledge studies," in order to, "more fully explore, comprehend, and appreciate indigenous people's lives and perspectives in a rapidly changing world (Lauer and Aswani 2009: 327)." In keeping with this call, many recent approaches to the study of knowledge converge on the recognition that knowledge is embedded in multiple systems of practice, beliefs, values, and power across all scales. As such, new concepts and methods are needed for studying and representing contemporary indigenous knowledge that traverses many different systems of understanding.

This special feature, based on an invited session of papers presented at the 2012 American Anthropological Association (AAA) annual meeting, explores key conceptual, methodological, practical, and ethical challenges and opportunities in studying indigenous knowledge systems and applying insights from such knowledge systems in scholarly, resource management, and local community venues across the globe. The papers in this feature represent geographic and topical diversity, while converging on several important themes facing anthropology and other fields that study knowledge systems.

First, to better describe and understand indigenous knowledge systems, several papers use a practice-oriented approach, a framework that enters the analysis assuming that knowledge involves social, dynamic, performative, and improvisational dimensions in addition to cognitive models and classification systems. Schareika (2014) examines the theoretical implications of rethinking knowledge as situated practice embedded in moral, social, and political contexts. Taking insights from critical approaches to knowledge, this set of papers explores how knowledge and linked cultural practices are socially constructed and differentially shared. Key questions include: What is knowledge? What is knowing? What is the relation between skills and practical knowledge? How do local people conceptualize knowledge? How can the richness and complexity of local knowledges and practices best inform studies of knowledge systems? Who should carry out such studies or interventions? How does knowledge vary among and between communities? What are the roles of researchers in constructing their own knowledge and representing that of others? What novel approaches are emerging that foster new sorts of relationships between indigenous or local communities and researchers?

Second, several papers discuss multiple ways of representing knowledge. Case studies by Carothers et al. (2014) and Spoon (2014) demonstrate that knowledge systems show contradiction, variation, and consensus. How might we best construct formal models of representation, or how do we represent not knowing? Are there patterns to variation based on social categories of difference or other factors? Here the feature explores a particularly pressing issue for anthropology and other fields. How do we best share the results of scientific studies? What are the larger impacts and engagements that result from such studies? Relatedly, the authors take up issues of ethics and collaborative methodologies, seeking to provide alternatives to how knowledge is studied and to what ends. Local and indigenous knowledge has become increasingly valued in global governance discourses focused on concerns about supporting cultural and biological diversity. Yet, there is little reflection on how current, more rigid conceptualizations of that knowledge shape assumptions about what is most important in efforts to sustain those diversities. We suggest that greater attention to the complexities of the processes of learning indigenous knowledge in a world undergoing rapid transformations requires more flexible pairing of methods and approaches. Recently, scholars and practitioners have developed education programs aimed at supporting indigenous knowledge in a variety of ways (Riuz-Mallen et al. 2010, Baines and Zarger 2012, McCarter et al. 2014), including activities that link elders and youth in outside of school contexts and develop curricula that integrate local knowledge into formal schooling. 
Third, with these questions about representation of indigenous and local knowledge and practice in mind, several authors explore collaborative research and the practical implications for what kind of knowledge is studied and how it is studied. The papers by Carothers et al. (2014), Velasquez Runk (2014), and Spoon (2014) provide a close look at contemporary challenges to collaborative research with indigenous and local groups and institutions. They examine key considerations such as locally relevant research questions and research design, communication of findings, control of research and its products, and the practical implications of collaborative research for researchers and local communities.

Throughout each of these themes, this special feature addresses critical and interrelated questions for the study and application of indigenous and local ways of knowing, including: 1) How are different forms of indigenous knowledge conceptualized by different actors, and what are the implications of these conceptualizations? 2) What are appropriate methods to study and represent these different forms of knowledge and practice? 3) To what extent are conceptualizations and methodological approaches mutually constitutive? 4) What are the ethical and practical implications of these conceptualizations, methodological approaches, and representations? We expect that this feature will be of key interest to students and scholars in a wide range of fields, as well as resource managers, practitioners, activists, indigenous peoples, among other interested groups.

Responses to this article can be read online at: http://www.ecologyandsociety.org/issues/responses. $\mathrm{php} / 7212$

\section{Acknowledgments:}

As guest editors, we thank the editors of Ecology and Society for welcoming this special feature and the many peer reviewers whose feedback greatly improved earlier drafts of the papers. We are grateful to the Anthropology and Environment Society, a section of the American Anthropological Association, who invited our panel at the 2012 annual meeting held in San Francisco, California. We thank the other panelists who participated in the panel, including: Marcus Barber, Trisia Farrelly, Andrew Flachs, Matt Lauer, Glenn Stone, as well as our discussants, Roy Ellen and Rick Stepp, who carefully reviewed and brought key commentary to bear on many of the key themes identified in this introduction and elaborated upon in the papers in this special feature.

\section{LITERATURE CITED}

Baines, K., and R. K. Zarger. 2012. Circles of value: integrating Maya environmental knowledge into Belizean schools. in $\mathrm{H}$. Kopnina, editor. Anthropology of Environmental Education. Nova Science Publishers.
Carothers, C., C. Brown, K. J. Moerlein, J. López, D. B. Andersen, and B. Retherford. 2014. Measuring perceptions of climate change in northern Alaska: pairing ethnography with cultural consensus analysis. Ecology and Society 19(4): 27. http://dx.doi. org/10.5751/ES-06913-190427

Hunn, E. 2007. Ethnobiology in four phases. Journal of Ethnobiology 27(1):1-10. http://dx.doi.org/10.2993/0278-0771 (2007)27[1:EIFP]2.0.CO;2

Lauer, M., and S. Aswani. 2009. Indigenous ecological knowledge as situated practices: understanding fishers' knowledge in the western Solomon Islands. American Anthropologist 11 (3):317-329. http://dx.doi.org/10.1111/j.1548-1433.2009.01135.x

Maffi, L. L., and E. Woodley. 2010. Biocultural diversity conservation: a global sourcebook. Earthscan, London.

McCarter, J., M. C. Gavin, S. Baereleo, and M. Love. 2014. The challenges of maintaining indigenous ecological knowledge. Ecology and Society 19(3): 39. http://dx.doi.org/10.5751/ ES-06741-190339

Reyes-Garcìa V., J. Broesch, L. Calvet-Mir, N. Fuentes-Peláez, T. W. McDade, S. Parsa, S. Tanner, T. Huanca, W. R. Leonard, M. R. Martínez-Rodríguez, and TAPS Bolivian Study Team. 2009. Cultural transmission of ethnobotanical knowledge and skills: an empirical analysis from an Amerindian society. Evolution and Human Behavior 30:274-285. http://dx.doi.org/10.1016/j. evolhumbehav.2009.02.001

Ruiz-Mallen, I., L. Barraza, B. Bodenhorn, M. de la Paz CejaAdame, and V. Reyes-Garcia. 2010. Contextualising learning through the participatory construction of an environmental education programme. International Journal of Science Education 13:1755-1770. http://dx.doi.org/10.1080/09500690903203135

Schareika, N. 2014. The social nature of environmental knowledge among the nomadic Wodaabe of Niger. Ecology and Society 19(4): 42. http://dx.doi.org//10.5751/ES-07056-190442

Spoon, J. 2014. Quantitative, qualitative, and collaborative methods: approaching indigenous ecological knowledge heterogeneity. Ecology and Society 19(3): 33. http://dx.doi. org/10.5751/ES-06549-190333

UNESCO. 2009. Learning and Knowing in Indigenous Societies Today. P. Bates, M. Chiba, S. Kube, and D. Nakashima, editors. UNESCO: Paris.

Velasquez Runk, J. 2014. Enriching indigenous knowledge scholarship via collaborative methodologies: beyond the high tide's few hours. Ecology and Society 19(4): 37. http://dx.doi. org/10.5751/ES-06773-190437

Zent, S. 2009. A geneaology of scientific representations of indigenous knowledge. Pages 19-67 in S. Heckler, editor. Landscape, Process, and Power: Re-evaluating Traditional Environmental Knowledge. Berghahn Books, New York, New York. 